\title{
Genetic divergence between genotypes of forage peanut in relation to agronomic and chemical traits
}

\section{Ana Paula Morais Menezes ${ }^{1}$, Giselle Mariano Lessa de Assis $^{2}$, Marcela Mataveli ${ }^{2}$, Hellen Sandra Freires da Silva ${ }^{1}$, José Marlo Araújo de Azevedo ${ }^{1}$, Márcia Silva de Mendonça ${ }^{3}$}

\footnotetext{
1 Universidade Federal do Acre.

2 Embrapa Acre.

3 União Educacional do Norte.
}

\begin{abstract}
The objective of this study was to evaluate the genetic divergence of forage peanut in relation to agronomic and chemical traits in both rainy and dry seasons. This experiment was conducted with genotypes from the Forage Peanut Active Germoplasm Bank located in Embrapa Acre. Eighteen genotypes of forage peanut were used: 12 genotypes of A. pintoi, four genotypes of the $A$. repens species and two interspecific hybrids of $A$. pintoi $\times$ A. repens. The design was of randomized blocks with five replicates. All traits were submitted to analyses of variance and later, study of genetic divergence was done through multivariate analysis techniques, in which the Tocher's optimization method and the nearest neighbor method were used. Dissimilarity measure used in cluster analysis was the generalized distance of Mahalanobis. No pattern was found in the cluster based on species used, according to the results. There is genetic variability for all traits except neutral detergent fiber, acid detergent fiber, hemicellulose and lignin in the rainy season and for pests in the dry season. The traits which presented most relative contribution in the study of genetic divergence of forage peanut were flowering, dry matter yield and average height in the rainy season and crude protein and average height in the dry season. The established cluster may help the breeder to choose parents and crossings to be selected in forage peanut breeding programs.
\end{abstract}

Key Words: Arachis, genetic improvement, multivariate analysis, Tocher's optimization

\section{Introduction}

Diversification of pastures in the Amazon associated to the use of adapted forage has been one of the most feasible alternatives for recovery of degraded areas. Introduction of forage legumes with the objective of reducing cutting down of forest areas has seemed to be a good alternative. Among the tropical forage legumes, wild species of the genus Arachis (Arachis pintoi Krapovickas \& Gregory, Arachis repens Handro and Arachis glabrata Benth.), known as forage peanut, have stood out because they present high persistence in intercrop systems and proper chemical characteristics.

A large collection of Arachis was created by Embrapa Recursos Genéticos e Biotecnologia based on genotypes collected in different regions in Brazil (Valls \& Pizarro, 1994). The genotypes which are part of this collection had been evaluated and used in some breeding programs in Brazil and in other countries as well (Pereira et al., 2001).

The study of genetic diversity by chemical analyses is very important in a breeding program, particularly at the beginning, for defining work strategies. Genetic variability, both spontaneous and created, is the starting point of any genetic improvement program of a species. Its manipulation by using adequate methods leads to the achievement of higher genotypes in relation to attractive agronomic traits (Araújo et al., 2002; Ivoglo, 2007).

Evaluation of genetic diversity by multivariate analysis has the advantage of using simultaneous influence of a set of traits in the determination of diversity, increasing the possibility of success in the selection of parents (Cruz et al., 1994; Cruz et al., 2004). Prediction of genetic diversity based on multivariate methods is advantageous because it does not use previous achievement of hybrid combinations in the evaluation of heterosis (Miranda et al., 1988). However, parents chosen based only on diversity are not regarded as a good improvement strategy because it does not take into account its "per se" performance, so it is necessary to combine diversity and performance.

The objective of this study was to evaluate genetic divergence between genotypes of forage peanut in relation to agronomic and chemical traits in the rainy and dry seasons, separately.

\section{Material and Methods}

The study was carried out with genotypes from Banco Ativo de Germoplasma - BAG (Active Germoplasm Bank) of 
forage peanut located in Embrapa Acre, in the city of Rio Branco, Acre. The average annual temperature in the region is $24.5^{\circ} \mathrm{C}$ with relative air humidity ranging from 80 to $90 \%$ and average annual rainfall of 1,877 to $1,982 \mathrm{~mm}$, with a rainy season from October to April and dry season from June to September (Acre, 2006).

Eighteen genotypes of forage peanut were used: 12 genotypes of the $A$. pintoi species, four genotypes of A. repens and two hybrids resulting from the $A$. pinto $\times$ A. repens interspecific crossing (Table 1). The experiment was set on Experimental Field Embrapa Acre with Oxisol with chemical characteristics as follows (at 0-20 cm depth): $\mathrm{K}-0.1 \mathrm{cmol}_{C} / \mathrm{dm}^{3}, \mathrm{Ca}^{+2}-1.6 \mathrm{cmol}_{\mathrm{C}} / \mathrm{dm}^{3}, \mathrm{Mg}^{+2}-0.4 \mathrm{cmol}_{C} / \mathrm{dm}^{3}$, $\mathrm{Al}^{+3}-1.0 \mathrm{cmol}_{\mathrm{C}} / \mathrm{dm}^{3}$ and CEC $-5.44 \mathrm{cmol}_{C} / \mathrm{dm}^{3} ; \mathrm{C}-0.74 \mathrm{dag} / \mathrm{kg}$; $\mathrm{P}$ - $2.0 \mathrm{mg} / \mathrm{dm}^{3}$; base saturation - 38.60\%; organic matter (OM) - 1.3\%; $\mathrm{pH}$ in water -5.4 . The design was of randomized blocks with five replicates. Each plot had a total area of $4 \mathrm{~m}^{2}$. Plots were formed by using two stolons with $25 \mathrm{~cm}$ of length or three seeds per hole, totaling 25 holes per plot, distributed in five rows with spacing of $0.5 \mathrm{~m}$ between plants. The sampling area was the central part of the plot, and $0.5 \mathrm{~m}$ of each edge was considered as borders, resulting in an useful area of $1.0 \mathrm{~m}^{2}$.

Th experimental area was fertilized according to soil analysis. Fifty kilograms of $\mathrm{P}_{2} \mathrm{O}_{5}$ (triple superphosphate) were applied per hectare, $40 \mathrm{~kg} \mathrm{~kg} / \mathrm{ha}$ of $\mathrm{K}_{2} \mathrm{O}$ (potassium chloride), $40 \mathrm{~kg} / \mathrm{ha}$ of FTE BR12.

The settling period was from December 2008 to April 2009, when the first harvest was performed (standardization). From this first harvest, agronomic evaluations were carried out (at every three months) and the chemical evaluations were done in the rainy and dry seasons in 2009 and 2010. Three harvest sessions were carried out in the rainy season and two in the dry season. The following characteristics were evaluated:

1) Total dry matter yield (kg/ha) - To determine dry matter, shoots were cut off, weighed, placed in a paper bag and oven-dried ( $55^{\circ} \mathrm{C}$ for 72 hours), then weighed again on a precision scale.

Table 1 - Forage peanut genotypes of BAG located in Embrapa Acre used in the present study

\begin{tabular}{lccc}
\hline BRA & Species & BRA & Species \\
\hline 039985 & A. pintoi & 012106 & A. repens \\
029220 & A. repens & 029190 & A. repens \\
012122 & A. pintoi & 029203 & A. repens \\
014982 & A. pintoi & 035076 & A. pintoi $\times$ A. repens \\
030325 & A. pintoi & 038857 & A. pintoi $\times$ A. repens \\
030601 & A. pintoi & 030384 & A. pintoi \\
031828 & A. pintoi & $040550 a$ & A. pintoi \\
039772 & A. pintoi & $040550 b$ & A. pintoi \\
040045 & A. pintoi & 013251 & A. pintoi \\
\hline
\end{tabular}

a - planted by using seedlings; b - planted by using seeds.
2) Leaf/stem ratio - approximately $150 \mathrm{~g}$ of the cut sample (green biomass) was separated into leaves (blade and petioles) and stem. Then they were weighed, placed in paper bags and taken to forced-circulation oven at $55^{\circ} \mathrm{C}$ for 72 hours, then weighed again on a precision scale.

3) Total dry matter accumulation rate $(\mathrm{kg} / \mathrm{ha} / \mathrm{day})$ Estimated by dividing total dry matter yield by the number of days between the adjacent harvests.

4) Nutritional value (\%) - samples of total biomass (leaves and stem) of a rainy season cut (January, 2010) and of a dry season were submitted to chemical analyses at Laboratory Bromatology of Embrapa Acre for the following determinations: dry matter (DM) according to the AOAC (1970); neutral detergent fiber (NDF) and acid detergent fiber (ADF) according to Georing \& Van Soest (1970); crude protein according to the modified method of Kjeldahl (Silva \& Queiroz, 2001); lignin, hemicellulose and cellulose, determined according to the methods proposed by Van Soest (1965).

5) Pests and diseases - occurrence of pests and diseases were evaluated before each harvest. The following evaluation scale was used: ( 0 - no damage; 1 - little damage with up to $33 \%$ of injured plants; 2 - little damage with up to $34 \%$ to $66 \%$ of plants injured; 3 - little damage with up to $67 \%$ to $100 \%$ of plants injured; 4 - moderate damage with up to $33 \%$ of plants injured; 5 - moderate damage with up to $34 \%$ to $66 \%$ of plants injured; 6 - moderate damage with $67 \%$ to $100 \%$ of plants injured; 7 - severe damage with up to $33 \%$ of plants dead; 8 - severe damage with up to $34 \%$ to $66 \%$ of plants dead; 9 - severe damage with $67 \%$ to $100 \%$ of plants dead).

7) Soil cover (\%) - evaluation of percentage of soil covered in $1 \mathrm{~m}^{2}$ of the useful area before each harvest.

8) Average height of the plant in the stand ( $\mathrm{cm}$ ) - average of three measurements evaluated in $1 \mathrm{~m}^{2}$ of the useful area with the aid of a centimeter ruler before each harvesting.

9) Plant vigor - evaluations in $1 \mathrm{~m}^{2}$ of the useful area, before each harvest, using the following scale: (1 - very bad; 2 - very bad to bad; 3 - bad; 4 - bad to regular; 5 - regular; 6 - regular to good; 7 - good; 8 - good to very good; 9 - very good).

10) Flowering (\%) - visual evaluation of percentage of flowers in $1 \mathrm{~m}^{2}$.

Means of the harvests performed in November 2009, January 2010 and April 2010 were used in evaluations of the rainy season for agronomic traits. Chemical analyses were done from samples of the harvest of January 2010.

In the dry season, means of the harvests performed in July 2009 and July 2010 were used for agronomic traits, and 
the results of July 2010 harvest were used for the chemical traits.

Means, minimum and maximum values, average heritability $\left(\mathrm{h}^{2}\right)$, experimental coefficient of variation (CVe) and coefficient of genetic variation $(\mathrm{CVg})$ were calculated for all the evaluated traits.

Multicolinearity diagnoses were carried out with the objective of discarding redundant traits. The methods used for diagnoses were the following: variance inflation factor (VIF), value of the determinant, number of correlation above 0.80 , examination of condition number $(\mathrm{CN})$ and autovalues of correlation matrix, according to the one proposed by Carvalho (1995).

After analyses of multicolinearity of the data and discarding of the needed traits, evaluation of genetic divergence was done among genotypes by using dissimilarity measures expressed by generalized distance of Mahalanobis. Following that, the optimization and the nearest neighbor methods were used for the rainy and dry seasons, separately. Diagnoses of multicolinearity and the other analyses were done through the software GENES (version Windows).

\section{Results and Discussion}

The genotypes presented significant differences for most of the evaluated traits, except for neutral detergent fiber (NDF), acid detergent fiber (ADF), hemicelulose and lignin (Table 2).

The resulting experimental coefficients of variation (CVe) were low, showing a good experimental accuracy. The highest values were found for flowering (40.23\%), diseases (32.74\%) and pests (25.09\%). However, variation between genotypes was high enough for allowing significant differences between effects of treatments for such traits.

High values of heritability $\left(\mathrm{h}^{2}\right)$ were found for most traits. Pests, vigor and flowering presented the highest heritability and the $\mathrm{CVe} / \mathrm{CVg}$ ratio was higher than the unit, thereby reflecting a favorable situation for selection.

Vigor, soil cover and crude protein presented low experimental coefficients of variation and values ranging from intermediate to high for heritability, showing that environment did not influence nor had little effect on expression of those traits.

When evaluating genotypes of Arachis spp. in Distrito Federal in the rainy season, Fernandes et al. (2009) found mean values ranging from $1,830 \mathrm{~kg} / \mathrm{ha}$ to $2,030 \mathrm{~kg} / \mathrm{ha}$ of dry matter yield in different harvests. In the same conditions, dry matter yield for the genotype BRA 040550 ranged from

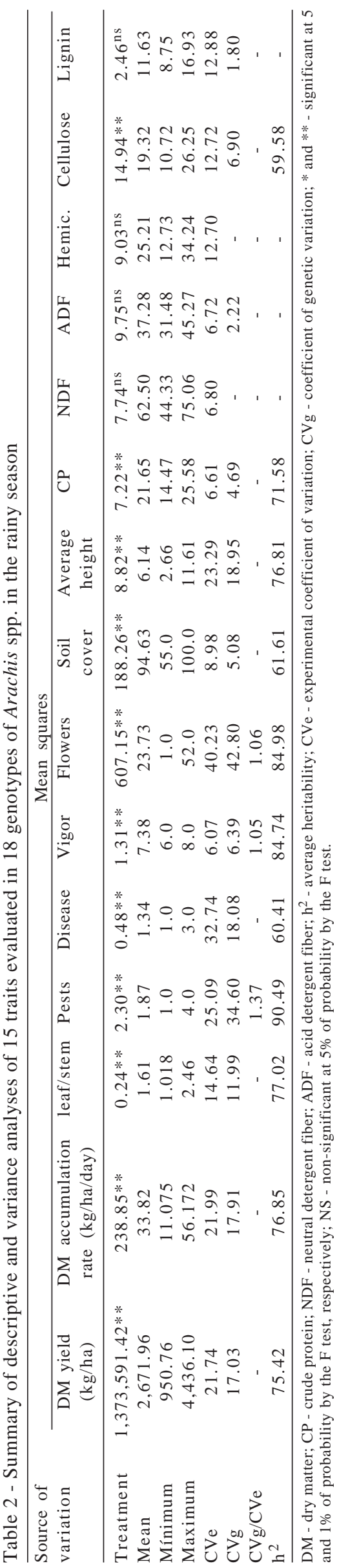

R. Bras. Zootec., v.41, n.7, p.1608-1617, 2012 
$960 \mathrm{~kg} / \mathrm{ha}$ to $1,510 \mathrm{~kg} / \mathrm{ha}$, which was lower than the ones found in this study. In Acre, Valentim et al. (2003) found a dry matter yield for genotype BRA 040550 higher than $3,000 \mathrm{~kg} / \mathrm{ha}$ and dry matter accumulation average rate of $25 \mathrm{~kg} / \mathrm{ha} /$ day. In this study, the Belmonte cultivar presented dry matter yield of $2,300 \mathrm{~kg} / \mathrm{ha}$ and accumulation rate of 20 to $22 \mathrm{~kg} / \mathrm{ha} / \mathrm{day}$. These results are similar to the ones found in the present study.

Assis et al. (2008) found values of 2.20 for the leaf/stem ratio in genotypes of forage peanut, which are results similar to the ones found in this study. However, Assis et al. (2009) found values below 0.32 for the same trait in a study carried out with Stylosanthes guianensis, showing that, overall, forage peanut presents greater amounts of leaves. Wilson \& T'Mannetje (1978) found that the high leaf/stem ratio represents forage with high levels of protein, digestibility and intake, in addition to having better adaptation to grazing and tolerance to cuts. However, the leaf/stem ratio should not be evaluated alone; selection is also based on dry matter yield and is very important, inasmuch as genotypes with a high leaf/stem ratio may present a very low yield of shoot biomass.

According to the National Research Council (NRC 1984), the minimum content of crude protein required to the supply of adult cattle feeding needs is $9 \%$, suggesting that the genotypes of this study are an excellent source of forage for this component.

The NDF and ADF values found in this study were higher than the ones found by Ladeira et al. (2002), who found values of $\mathrm{NDF}=52.5 \%$ and $\mathrm{ADF}=35.8 \%$ in hay of $A$. pintoi harvested at 100 days of age. Those authors used only one genotype, which explains this difference, inasmuch as the values found by Ladeira et al. (2002) are between the minimal and maximal obtained in this study. According to Van Soest (1982), the higher the content of NDF, the lower the intake of dry matter, and the higher the content of ADF, the lower its digestibility.

Teixeira et al. (2010), in a study with A. pintoi cv. Amarillo, found values between the minimal and the maximal values of this study for contents of cellulose (16.1\%), hemicellulose (16.0\%) and lignin (9.9\%) in a harvesting performed 102 days after transplanting.

$\mathrm{The} \mathrm{CVg} / \mathrm{CV}$ e ratio was higher than the unit for the traits pests, vigor and flowering, thus reflecting a very favorable situation to selection.

According to the results from analyses of variance, genotypes did not present any variation for NDF, ADF, hemicellulose or lignin, which were not considered in the study of genetic divergence. Dry matter accumulation rate, pests, diseases and vigor were also excluded because they were causing multicolinearity to the data set. Thus, multivariate analysis for study of genetic divergence in the rainy season was carried out based on the traits of dry matter yield, leaf/stem ratio, flowering percentage, covered solid percentage, average height, contents of crude protein and cellulose.

This method gave the opportunity to gather genotypes in similarity groups, with homogeneity within the group and heterogeneity between the groups (Table 3).

According to the results, it was found that there was no pattern in the cluster based on the species, because, as previously reported, most groups were formed by genotypes of distinct species. This result reinforces the need of studying genetic divergence based on traits interesting for breeding, especially when it is desirable to select parents to be included in hybridization programs.

In a study with genotypes of forage peanut carried out by Valentim et al. (2003), dry matter yield, crude protein yield, stolon lateral growth, soil cover, plant vigor, height of the plants and survival rate of seedlings evaluated 120 days after planting made it possible, along with the Tocher method, that genotypes BRA 031828, BRA 040550 and BRA 013251 stayed together in the first group, a result similar to the one of this study, despite the differences among the evaluated traits.

The Tocher's method was efficient in the study of genetic diversity for several species such as: oats (Machioro et al., 2003), elephant-grass (Cavalcante \& Lira, 2010), sweet cassava (Zuin et al., 2009), soybean (Matsuo et al., 2005), peanuts (Bloisi, 2011), and others.

Table 3 - Cluster of forage peanut genotypes by the Tocher's method based on the generalized distance of Mahalanobis for the rainy season

\begin{tabular}{|c|c|}
\hline Cluster & Genotype \\
\hline 1 & BRA 012106 (Ar), BRA 029203 (Ar), BRA 040045 (Ap), BRA 031828 (Ap), BRA 014982 (Ap), BRA 040550a (Ap), \\
\hline & BRA 030325 (Ap), BRA 039985 (Ap), BRA 035076 (Ap×Ar) \\
\hline 2 & BRA 012122 (Ap), BRA 013251 (Ap), BRA 040550b (Ap) \\
\hline 3 & BRA 029190 (Ar), BRA 030384 (Ap) \\
\hline 4 & BRA 029220 (Ar), BRA 039772 (Ap) \\
\hline 5 & BRA 038857 (Ap×Ar) \\
\hline 6 & BRA 030601 (Ap) \\
\hline
\end{tabular}


The traits which most contributed to the diversity were flowering (27.11\%), dry matter yield (18.10\%), and average height (17.06\%) (Table 4), and the ones which least contributed were cellulose (7.24\%) and soil cover (4.69\%) and they might be excluded in future evaluations, and the others will not. When studying genetic diversity in genotypes of forage peanut, Valentim et al. (2003) found that the least interesting variables were: plant vigor, soil cover and height during the settling period.

Soil cover is an important trait when it is evaluated during the forage peanut settling period (Assis et al., 2008), with the maximum variability found between the 12th and 16th weeks after planting in the soil and climate conditions of Acre. However, after the settling period, this importance seemed to decrease, as shown in this study in function of the lowest variability found.

Cluster method based on the nearest neighbor was also carried out. In this method, formation of clusters was done by considering a genetic distance of $45 \%$ (Figure 1 ).

Table 4 - Relative contribution of (S.j) of traits soil cover, cellulose, crude protein, leaf/stem ratio, average height, dry matter yield (DMY) and flowering in the rainy season

\begin{tabular}{lcc}
\hline Variable & S.j & Value (\%) \\
\hline Soil cover & 109.25 & 4.69 \\
Cellulose & 168.57 & 7.24 \\
Crude protein & 274.41 & 11.79 \\
Leaf/stem ratio & 325.07 & 13.97 \\
Average height & 396.83 & 17.06 \\
Dry matter intake & 421.06 & 18.10 \\
Flowering & 630.57 & 27.11 \\
\hline
\end{tabular}

Formation of nine groups was identified by observing the dendogram. Similarly to what was observed by the Tocher's optimization method, the hierarchical method of the nearest neighbor also presented genotype BRA 012106 and BRA 029203 close to each other. Genotypes BRA 012122 and BRA 013251 were in the same group as BRA 014982, BRA 040045 and BRA 040550, and the genotypes BRA 029220 and BRA 040550 were in unitary groups.

According to this technique, genotype BRA 029220 was the most divergent, isolated in the last group. Genotypes BRA 012106 and BRA 029203 were the most similar ones, staying in the same group, confirming their proximity by the studied traits.

As in the Tocher's method, the hybrids, genotypes BRA 035076 and BRA 038857 were in distinct groups relatively far from each other as well as the genotypes BRA 029220 and BRA 020190 of A. repens.

In a study conducted by Azevedo et al. (2011), using morphological traits and the method of the nearest neighbor, the genotypes BRA 012106 and BRA 029203 were also close, and the genotypes BRA 029220 and BRA 029203 were in distinct clusters, evincing the results of this study.

The results confirm the potential use of agronomic traits, which, along with the quantitative genetic techniques, has been helping, in a direct manner, the breeder to develop new cultivars. Based on the divergence and on studies of agronomic superiority, the breeder can select genotypes and guide the crossings, aiming at the best heterotic effect and greater heterozigosity. Thus, crossing of parents belonging to the same group should be avoided, according to the methods used.

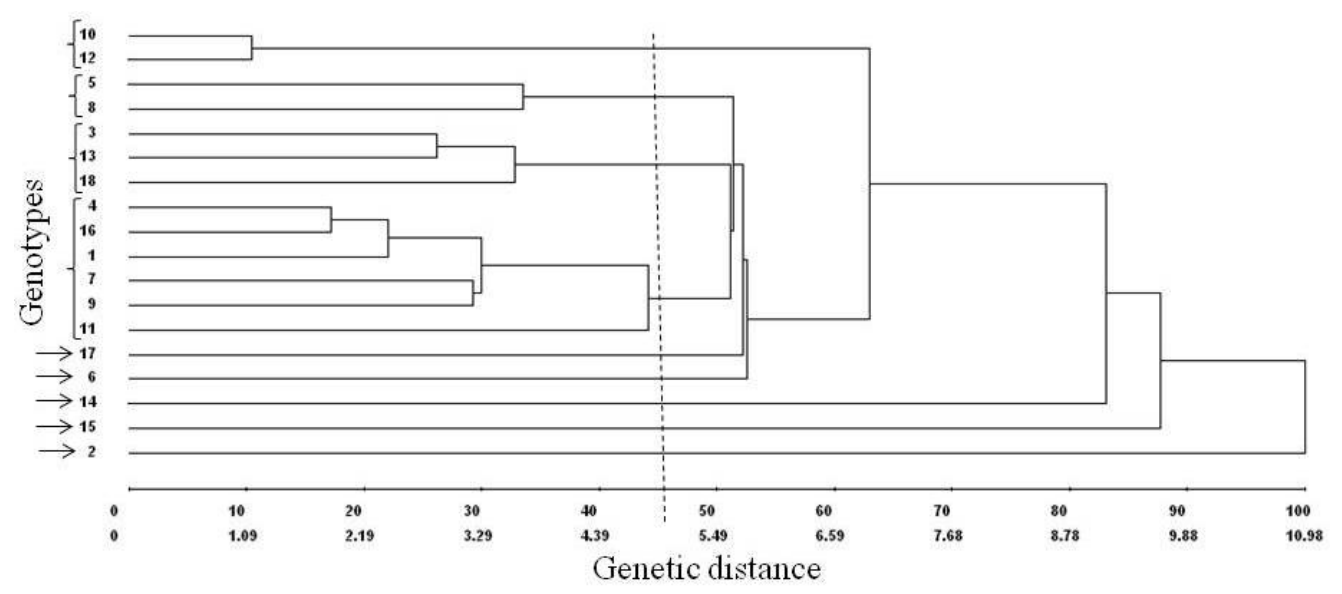

Note: (1) BRA 039985, (2) BRA 029220, (3) BRA 012122, (4) BRA 014982, (5) BRA 030325, (6) BRA 030601, (7) BRA 031828, (8) BRA 039772, (9) BRA 040045, (10) BRA 012106, (11) BRA 029190, (12) BRA 029203, (13) BRA 035076, (14) BRA 038857, (15) BRA 030384, (16) BRA 040550, (17) BRA 040550*, (18) BRA 013251 *Planted by using seeds.

Figure 1 - Dendogram of genetic dissimilarities between genotypes of forage peanut, obtained by the hierarchical method of the nearest neighbor by using the generalized distance of Mahalanobis. 
The effect of genotypes was significant for all traits, except for pests (Table 5). Genetic variation is favorable for the study of genetic diversity and shows the possibility of improvement for those traits.

According to analysis of variance, magnitude of the experimental coefficients of variation (CVe) and coefficient of genetic variation $(\mathrm{CVg})$ and heritability $\left(\mathrm{h}^{2}\right)$ varied in the dry season. Neutral detergente fiber, acid detergent fiber and crude protein presented the lowest values of CVe, showing that these traits were less influenced by the environment; the highest CVe was for flowering (54.72\%).

Vigor, ADF and crude protein presented low CVe and high heritability, showing that the environment did not influence or had little effect on those traits; heritability presented by dry matter yield, accumulation rate, disease, vigor, soil cover, height and crude protein which presented $\mathrm{h}^{2}$ above $85 \%$.

Means found for the dry season were lower than the means found for the rainy season for most traits, except for pests and diseases, which presented higher means in the dry season, showing a greater incidence of pests and diseases in this season.

As found in this study, Soares Filho et al. (2002) found greater dry matter yields in the rainy season when evaluating forages in the state of São Paulo.

When evaluating cultivars of Panicum maximum, Pueraria phaseoloides, Arachis glabrata cv. Arbrook and Arachis pintoi BRA 015121, Valentim \& Moreira (2001) found values for dry matter yield of $2.010 \mathrm{~kg} / \mathrm{ha}$ for cultivar A. pintoi BRA 015121 in the dry season in Acre, which was higher than the ones found for other forages, demonstrating that forage peanut was able to accumulate dry matter even in the season with the lowest rainfall.

Greater yields were also found by Carneiro et al. (2000), in which cultivar Belmonte (BRA 031828) presented accumulated dry matter yield of $15.340 \mathrm{~kg} / \mathrm{ha}$ in the rainy season and $3.750 \mathrm{~kg} / \mathrm{ha}$ of DM/ha in the dry season. Similarly to this study, this genotype was one of the most productive ones in the harvests performed in the dry season, presenting excellent adaptation and potential for forage production in the environmental conditions in Acre.

When dry matter yield is evaluated at each harvest, Valentim \& Andrade (2003) found similar results for genotypes Belmonte(3,608 kg/ha), BRA 040550 (3,710 kg/ha) and Amarillo (3,770 kg/ha), evaluated after the settling period in the dry season in Rio Branco, Acre.

Regarding dry matter accumulation rate, Andrade et al. (2004) found a rate of $23.0 \mathrm{~kg} / \mathrm{ha} /$ day for cultivar Belmonte. This amount is similar to the one found in this study, which was $24.09 \mathrm{~kg} / \mathrm{ha} /$ day in the dry season.

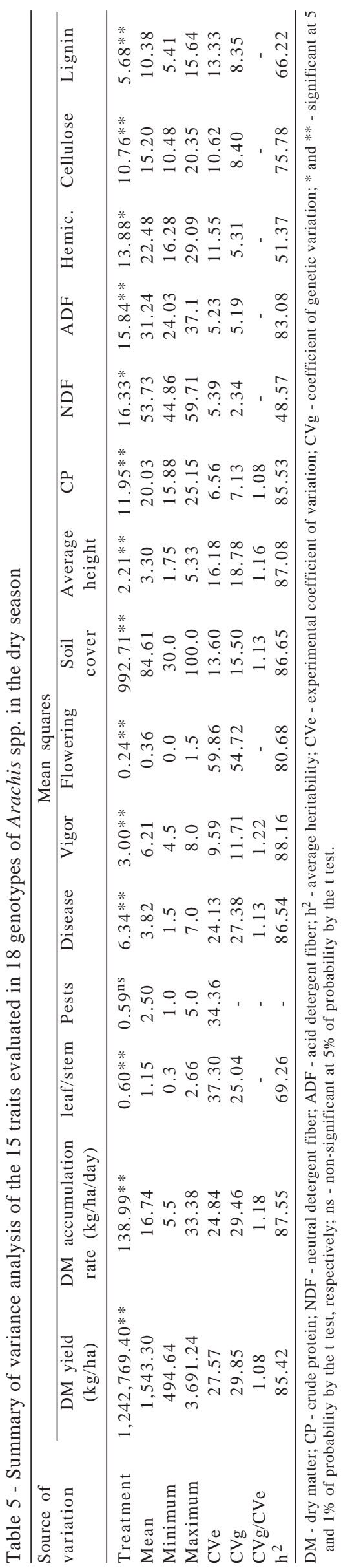

R. Bras. Zootec., v.41, n.7, p.1608-1617, 2012 
Silva et al. (2010) found for genotype BRA 040550 a leaf/ stem ratio of 1.09 in the dry season. In this experiment, an average leaf/stem ratio of 1.61 was found in the rainy season, and 1.15 in the dry season. According to a report by Silva (2004), forage peanut survives in the dry season in well drained areas, despite a severe loss of leaves (Silva, 2004).

The means found for the incidence of pests and diseases in the dry season were greater than those found in the rainy season. This fact can be explained by the warm climate conditions $\left(>30^{\circ} \mathrm{C}\right)$, which favors the severity of diseases in forage peanut plants (Moraes, 2006).

Results for contents of crude protein are directly related to leaf/stem ratio in Cynodon. Those which provided forage with greater contents of crude protein were the ones which presented higher leaf/stem ratio (Alvim et al., 2003). The same ratio was also found for genotypes of forage peanut evaluated in this study.

Cecato et al. (2004) found lower values of NDF and ADF in leaves of Arachis pintoi than in leaves of Coastcross. Gomes et al. (2003) also found higher quality of cv. Alqueire in comparison with the forage (nilograss, hemarthria and Bermuda grass) evaluated for contents of ADF, NDF and crude protein. Godoy et al. (2003) found values of NDF and ADF of $42.6 \%$, and $23.9 \%$, respectively, for forage peanut. Those values are lower than the ones found for other forages such as leucaena and stylosanthes, showing that even in the dry season, forage peanut presents forage of better quality.

Divergent results were found by Espindola et al. (2006) when evaluating $A$. pintoi for use in ground cover: values of $9.1 \%, 15.2 \%$ and $12.0 \%$ were found for hemicellulose, cellulose and lignin, respectively, in the dry season".

Forage peanut of the species Arachis pintoi. Krapov \& W.C. Gregory for use in soil cover. Values of $9.1 \%, 15.2 \%$ and $12.0 \%$ were found for hemicellulose, cellulose and lignin, respectively in the dry season. When evaluating levels of shade on forage peanut (A. pintoi cv. Amarillo), Gobbi et al. (2009) found contents of 25.3, 20.15 and 4.9\% of cellulose, hemicellulose and lignin, respectively, in forage peanuts submitted to $50 \%$ of shade, showing that this is a forage with potential use in silvopasture system without affecting its quality.

Dry matter yield, accumulation rate, diseases, vigor, soil cover, average height and crude protein all present $\mathrm{CVg} / \mathrm{CV}$ ratio greater than the unity, reflecting a favorable situation to selection.

The results of the study on genetic divergence between the 18 genotypes evaluated in the dry season, based on dry matter yield, leaf/stem ratio, flowering, soil cover, average height, crude protein and hemicelulose will be presented. Pests were excluded of this method due to the lack of variability among genotypes. Accumulation rate, disease, vigor, NDF, ADF, cellulose and lignin were all excluded because they caused multicolinearity among variables.

According to the method of Tocher, six clusters were formed (Table 6), which was a number equal to the one in the rainy season. The first cluster was formed by four genotypes, three genotypes of $A$. repens and A. pintoi species and one A. pintoi $\times A$. repens hybrid. The second cluster was formed by nine genotypes, seven genotypes of $A$. pintoi species and two $A$. pintoi $\times A$. repens hybrids. The third cluster was formed by two genotypes of $A$. pintoi. The fourth, fifth and sixth clusters were formed by only one genotype each, represented by genotypes of $A$. pintoi, A. repens and A. pintoi species, respectively. The occurrence of clusters with only one genotype evidences the wide diversity inasmuch as genotypes in unitary clusters are more dissimilar in relation to the set. According to those results, it was found that there was no pattern in the cluster based on the species because, as previously reported, most clusters were formed by genotypes of distinct species. However, in the dry season, there was more concentration of $A$. repens in the first cluster and two hybrids remained in the same cluster, along with other genotypes of A. pintoi.

Genotypes BRA 012106, BRA 029203 and BRA 040045 remained together in the first cluster in both rainy and dry seasons, similarly to genotypes BRA 013251 and BRA 040550b, which remained in the second group in both seasons. Genotypes BRA 035076, BRA 039985, BRA 031828 and BRA 040550a also remained clustered in the rainy and

Table 6 - Clusters of genotypes of forage peanut by Tocher's method based on the generalized distance of ( $\left.D^{2}\right)$ for the dry season

\begin{tabular}{cl}
\hline Cluster & \multicolumn{1}{c}{ Genotype } \\
\hline 1 & BRA 012106 (Ar), BRA 029203 (Ar), BRA 040045 (Ap), BRA 029190 (Ar) \\
2 & BRA 035076 (Ap×Ar), BRA 013251 (Ap), BRA 040550b (Ap), BRA 030601 (Ap), BRA 038857 (Ap×Ar), BRA 039985 \\
3 & (Ap), BRA 031828 (Ap), BRA 040550a (Ap), BRA 030384 (Ap) \\
4 & BRA 012122 (Ap), BRA 030325 (Ap) \\
5 & BRA 039772 (Ap) \\
6 & BRA 029220 (Ar) \\
\hline Ar- A. repens; Ap - A. pintoi; Ap $\times$ Ar - A. pintoi $\times$ A. repens.
\end{tabular}


dry seasons. On the other hand, genotypes in the same cluster in the rainy season were separated in the dry season, as occurred with BRA 029190 and BRA 030384 and with genotypes BRA 029220 and BRA 039772.

Formation of unitary clusters with genotypes BRA 039772, BRA 029220 and BRA 014982 was also found, showing that those are more dissimilar in relation to the formed clusters. Those were also the genotypes which presented the smallest dry matter yields. Tocher's optimization method clusters genotypes, keeping the criterion that distances within clusters are always shorter than between clusters (Cruz, 2006). Thus, the evaluated traits may be regarded as efficient in the differentiation of genotypes of forage peanut inasmuch as three clusters were formed with only one genotype, showing that they presented high magnitude distances in which they were not allocated with other genotypes, so they were distinct form the others when the seven evaluated traits are regarded.

Crude protein (22.47\%) and average height (21.67\%) were the traits which most contributed to diversity in the dry season, and the traits which least contributed were hemicelulose (4.71\%) and leaf/stem ratio (6.50\%) (Table 7). These results evince the greater importance of crude protein in genotypic discrimination in the dry season. In the rainy season, the trait which contributed most was flowering (27.11\%). In the dry season, this trait was among the ones with the greatest relative contribution, showing that this trait should not be discarded in future evaluations. It can be seen that soil cover had greater importance in the dry season than in the rainy season inasmuch as variation of genotypes were greater in the dry season because of the higher soil exposition presented by some genotypes.
Table 7 - Relative contribution(S.j) of hemicellulose, leaf/stem ratio, flowering, dry matter yield, soil cover, average height and crude protein of the dry season

\begin{tabular}{lcc}
\hline Variable & S.j & Value (\%) \\
\hline Hemicellulose & 114.51 & 4.71 \\
Leaf/stem ratio & 158.03 & 6.50 \\
Flowering & 317.26 & 13.05 \\
Dry matter yield & 372.33 & 15.32 \\
Soil cover & 395.00 & 16.25 \\
Average height & 526.55 & 21.67 \\
Crude protein & 546.15 & 22.47 \\
\hline
\end{tabular}

When studying genetic diversity in genotypes of forage peanuts, Valentim et al. (2003) found that one of the least interesting traits would be soil cover and height of plants for the establishment period. As previously presented, soil cover and height of plants presented high contribution, showing that choice of traits also depends on the time of evaluation and formation and development stage of the culture.

Hemicellulose was the least important trait in the dry season. In the rainy season, hemicelulose was one of the traits excluded from the analysis because it was causing problems in multicolinearity, and it must be underscored that this trait can be discarded from future studies since it was not important in any of the evaluated periods.

The cluster method based on the nearest neighbor was performed in the dry season as well as in the rainy season. In this method, formation of clusters was carried out subjectively considering a genetic distance of $48 \%$ (Figure 2). By observing the dendogram, found formation of six clusters was found, in which the first cluster is formed by genotypes BRA 012106 and BRA 029203 as well as in the rainy season.

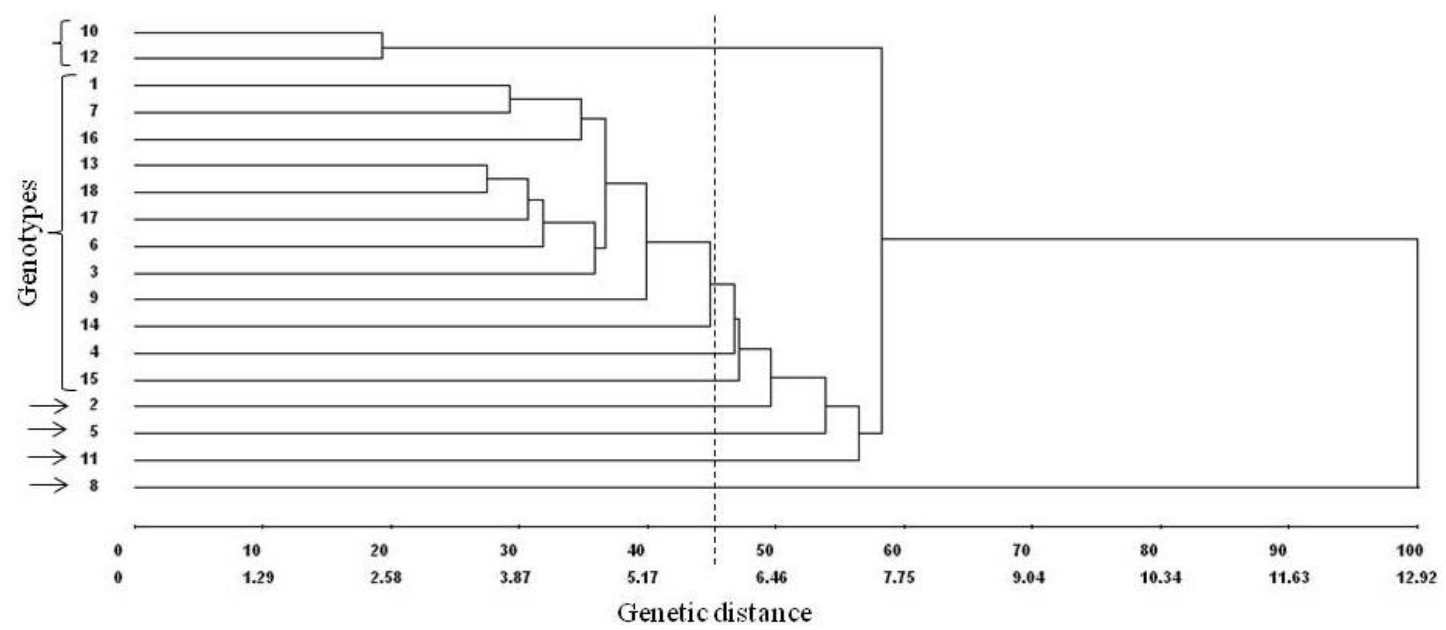

Note: (1) BRA 039985, (2) BRA 029220, (3) BRA 012122, (4) BRA 014982, (5) BRA 030325, (6) BRA 030601, (7) BRA 031828, (8) BRA 039772, (9) BRA 040045, (10) BRA 012106, (11) BRA 029190, (12) BRA 029203, (13) BRA 035076, (14) BRA 038857, (15) BRA 030384, (16) BRA 040550, (17) BRA 040550*, (18) BRA 013251 *Planted using seeds.

Figure 2 - Dendogram of genetic dissimilarities between genotypes of forage peanut, resulting from the Hierarchical method of the nearest neighbor, using generalized distance of Mahalanobis. 
The second and largest cluster allocated most genotypes (12 genotypes), presenting genotypes of species Arachis pintoi and Arachis repens. It was also found that two interspecific hybrids were allocated in the second cluster. According to the Nearest Neighbor technique, genotype BRA 039772 was the most divergent one, isolated in the last group. Genotypes BRA 012106 and BRA 029203 were the most similar ones, remaining in the same cluster, confirming their proximity by the studied traits in the dry season and in the rainy season as well. It was also found that genotypes of different species were allocated in the same group, showing great similarity.

\section{Conclusions}

There is genetic variability among the evaluated genotypes, except for neutral detergent fiber, acid detergent fiber, hemicelulose and lignin in the rainy season, and in the dry season for pests. The traits which presented CVg/CV ratio higher than one showed to be favorable to selection. The studied genotypes presented genetic divergence, allowing the establishment of distinct clusters in the rainy season as well as in the dry season. In the study on the genetic divergence of forage peanut, the traits which present the greatest relative contribution are flowering, dry matter yield and average height in the rainy season and crude protein and average height in the dry season. Hemicelulose can be discarded from future studies because it does not present high relative contribution in any of the evaluated periods. The clusters established through Tocher's optimization method can help the breeder chose parents and crossings to be carried out in programs of genetic improvement of forage peanut.

\section{References}

ACRE. Governo do Estado do Acre. Programa Estadual de Zoneamento Ecológico-Econômico do Estado do Acre. Zoneamento ecológico-econômico do Acre Fase II: documento síntese - Escala 1: 250.000. Rio Branco: SEMA, 2006. 354p.

ALVIM, M.J.; BOTREL, M.A.; REZENDE, H. et al. Avaliação sob pastejo do potencial forrageiro de gramíneas do gênero Cynodon, sob dois níveis de nitrogênio e potássio. Revista Brasileira de Zootecnia, v.32, n.1, p.47-54, 2003.

ANDRADE, C.M.S.; VALENTIM, J.F.; CARNEIRO, J.C. et al. Crescimento de gramíneas e leguminosas forrageiras tropicais sob sombreamento. Pesquisa Agropecuária Brasileira, v.39, n.3, p.263-270, 2004.

ARAÚJO, D.G.; CARVALHO, S.P.; ALVES, R.M. Divergência genética entre clones de cupuaçuzeiro (Theobroma grandiflorum Willd ex Spreng Schum). Ciência e Agrotecnologia, v.26, p.13-21, 2002

ASSIS, G.M.L.; VALENTIM, J.F.; CARNEIRO JÚNIOR, J.M. et al. Variabilidade genotípica de caracteres agronômicos em genótipos de amendoim forrageiro na Amazônia Ocidental. In: REUNIÃO ANUAL DA SOCIEDADE BRASILEIRA DE ZOOTECNIA, 45. 2008, Lavras. Anais... Lavras: SBZ, 2008. (CD-ROM).

ASSIS, G.M.L.; VALENTIM, J.F.; CUSTÓDIO, D.P. Variabilidade e correlações genotípicas entre características agronômicas durante o período de estabelecimento de genótipos de Stylosanthes guianensis no Acre. In: REUNIÃO ANUAL DA SOCIEDADE BRASILEIRA DE ZOOTECNIA, 46., 2009, Maringá. Anais... Maringá: SBZ, 2009. (CD-ROM).

ASSOCIATION OF OFFICIAL AGRICULTURA CHEMISTS - AOAC. Oficial methods of analysis. 15.ed. Washington, D.C., 1970. 1141p.

AZEVEDO, J.M.A.; SILVA, H.S.F.; ASSIS, G.M.L. et al. Genetic divergence among accessions of Arachis repens based on vegetative morphological traits. Revista Brasileira de Zootecnia, v.40, p.2067-2073, 2011.

BLOISI, L.F.M. Variabilidade morfológica e seleção de genótipos de amendoim tipo vagem lisa cultivados por agricultores familiares do recôncavo baiano. 2011. 66f Dissertação (Mestrado em Recursos Genéticos Vegetais) Universidade Federal do Recôncavo da Bahia, Cruz das Almas.

CARNEIRO, J.C.; VALENTIM, J.F.; PESSÔA, G.N. Avaliação agronômica do potencial forrageiro de Arachis spp. nas condições ambientais do Acre. In: REUNIÃO ANUAL DA SOCIEDADE BRASILEIRA DE ZOOTECNIA, 37., Viçosa, MG. Anais... Viçosa, MG: SBZ, 2000. (CD-ROM).

CARVALHO, S.P. Métodos alternativos de estimação de coeficientes de trilha $e$ índices de seleção, sob multicolinearidade. 1995. 163f. Tese (Doutorado em Genética e Melhoramento) - Universidade Federal de Viçosa, Viçosa, MG.

CAVALCANTE, M.; LIRA, M.A. Variabilidade genética em Pennisetum purpureum Schumacher. Revista Caatinga, v.23, n.2, p.153-163, 2010.

CECATO, U. et al. Acúmulo e utilização de forragem de coastcross (Cynodon dactylon [L]. Pers. cv. Coastcross-1) consorciada com Arachis (Arachis pintoi Krapovickas y Gregori) com e sem adubação nitrogenada. In: REUNIÃO ANUAL DA SOCIEDADE BRASILEIRA DE ZOOTECNIA, 41., 2004, Campo Grande. Anais... Campo Grande, 2004. (CD-ROM).

CRUZ, C.D.; CARVALHO, S.P.; VENKOVSKY, R. Estudos sobre divergência genética. II. Eficiência da predição do comportamento de híbridos com base na divergência de progenitores. Revista Ceres, v.41, n.234, p.178-182, 1994.

CRUZ, C.D.; REGAZZI, A.J.; CARNEIRO, P.C.S. Modelos Biométricos aplicados ao melhoramento genético, Viçosa, MG: UFV, 2004. v.1, 480p.

ESPINDOLA, J.A.A; GUERRA, J.G.M.; ALMEIDA, D.L. et al. Decomposição e liberação de nutrientes acumulados em leguminosas herbáceas perenes consorciadas com bananeira. Revista Brasileira de Ciência do Solo, v.30, p.321-328, 2006.

FERNANDES, F.D.; RAMOS, A.K.B.; GUIMARÃES JÚNIOR, R. et al. Produtividade de massa seca de genótipos de Arachis spp. no Distrito Federal. In: REUNIÃO ANUAL DA SOCIEDADE BRASILEIRA DE ZOOTECNIA, 46., 2009, Maringá. Anais... Maringá: SBZ, 2009. (CD-ROM).

GEORING, H.K.; VAN SOEST, P.J. Forage fiber analysis: apparatus, reagents, procedures and some applications. Washington: USDAARS Agricultural Handbook, 1970. 379p.

GOBBI, K.F.; GARCIA, R.; GARCEZ NETO, A.F. Características morfológicas, estruturais e produtividade do capim-braquiária e do amendoim forrageiro submetidos ao sombreamento. Revista Brasileira de Zootecnia, v.38, n.9, p.1645-1654, 2009.

GODOY, P.B.; BUENO, I.C.S; CABRAL FILHO, S.L.S. et al. Caracterização de leguminosas forrageiras quanto à composição química e à quantificação de taninos. In: REUNIÃO ANUAL DA SOCIEDADE BRASILEIRA DE ZOOTECNIA, 40., 2003, Santa Maria. Anais... Santa Maria, 2003. (CD-ROM). 
GOMES, J.F.; REIS, J.C.L.; STUMPF JÚNIOR, W. Qualidade da forragem de espécies perenes de estação quente em solo heteromórfico no sudeste do Rio Grande do Sul. In: REUNIÃO ANUAL DA SOCIEDADE BRASILEIRA DE ZOOTECNIA, 40., 2003, Santa Maria. Anais... Santa Maria, 2003. (CD-ROM).

IVOGLO, M.G. Divergência genética entre progênies de café robusta. 2007. 87f. Dissertação (Mestrado em Agricultura Tropical e Subtropical) - Instituto Agronômico de Campinas, Campinas.

LADEIRA, M.M.; RODRIGUEZ, N.M.; BORGES, I. et al. Avaliação de feno de Arachis pintoi utilizando ensaios de digestibilidade in vivo. Revista Brasileira de Zootecnia, v.31, n.6, p.2350-2356, 2002.

MACHIORO, V.S.; CARVALHO, F.I.F.; OLIVEIRA, A.C. et al. Dissimilaridade genética entre genótipos de aveia. Ciência Agrotecnica, v.27, n.2, p.285-294, 2003.

MATSUO, E.; SEDIYAMA, T.; OLIVEIRA, R.C.T. et al. Diversidade genética de genótipos de soja com base na avaliação de descritores adicionais. In: CONGRESSO BRASILEIRO DE MELHORAMENTO DE PLANTAS, 5., 2005, Guarapari. Anais... Guarapari, 2005. (CD-ROM).

MIRANDA, J.E.C; CRUZ, C.D; COSTA, C.P. Predição do comportamento de hibridos de pimentão (Capsicum annum L.) pela divergência genética dos progenitores. Revista Brasileira de Genética, v.11, n.4, p.929-937, 1988.

MORAES, S.A. Amendoim: Principais doenças, manejo integrado e recomendações de controle. 2006. Available at: <http:// www.infobibos.com/Artigos/2006_2/amendoim/Index.htm>. Accessed on: June 18, 2011.

NATIONAL RESEARCH COUNCIL - NRC. Nutrient requeriments of beef cattle. 6.ed. Washington: National Academy Press, 1984. 90p.

PEREIRA, A.V.; VALLE, C.B.; FERREIRA, R.P. et al. Melhoramento de forrageiras tropicais. In: NASS, L.L.; VALOIS, A.C.C.; MELO, I.S. et al. (Eds.); Recursos genéticos e melhoramento - Plantas. Rondonópolis: Fundação MT, 2001. p.549-601.

SILVA, D.J.; QUEIROZ, A.C. Análise de alimentos: métodos químicos e biológicos. 3.ed. Viçosa, MG: UFV, 2001. 235p.

SILVA, H.S.F.; ASSIS, G.M.L.; REIS, S.S.O. et al. Desempenho produtivo do amendoim forrageiro em função do tamanho do fruto. In: REUNIÃO ANUAL DA SOCIEDADE BRASILEIRA DE ZOOTECNIA, 47., 2010, Salvador. Anais... Salvador: Sociedade Brasileira de Zootecnia, 2010. (CD-ROM).
SILVA, M.P. Amendoim forrageiro - Arachis pintoi. Fauna e flora do cerrado, Campo Grande, Novembro 2004. Available at: <http://www.cnpgc.embrapa.br/ rodiney/series/arachis/arachis.htm>. Accessed on: Aug. 3, 2011.

SOARES FILHO, C.V.; RODRIGUES, L.R.A.; PERRI, S.H.V. Produção e valor nutritivo de dez gramíneas forrageiras na região Noroeste do estado de São Paulo. Acta Scientiarum, v.24, n.5, p.1377-1384, 2002.

TEIXEIRA, V.I.; DUBEUX JÚNIOR, J.C.B.; SANTOS, M.V.F. et al. Aspectos agronômicos e bromatológicos de leguminosas forrageiras no Nordeste Brasileiro. Archivos de Zootecnia, v.59, n.226, p.245-254, 2010.

VALENTIM, J.F.; ANDRADE, C.M.S. Partição de biomassa e banco de sementes de acessos de amendoim forrageiro na Amazônia Ocidental brasileira. In: REUNIÃO ANUAL DA SOCIEDADE BRASILEIRA DE ZOOTECNIA, 40., 2003, Santa Maria. Anais... Santa Maria: SBZ, 2003. (CD-ROM).

VALENTIM, J.F.; ANDRADE, C.M.S.; MENDONÇA, H.A. et al. Velocidade de estabelecimento de genótipos de amendoim forrageiro na Amazonia Ocidental. Revista Brasileira de Zootecnia, v.32, n.6, p.1569-1577, 2003.

VALENTIM, J.F.; MOREIRA, P. Produtividade de forragem de gramíneas e leguminosas em pastagens puras e consorciadas no Acre. Rio Branco: Embrapa Acre, 2001. 37p. (Boletim de pesquisa e desenvolvimento, 33).

VALLS, J.F.M.; PIZARRO, E.A. Collection of wild Arachis germplasm. In: KERRIDGE, P.C.; HARDY, B. (Eds.) Biology and agronomy of forage Arachis. Cali: Centro Internacional de Agricultura Tropical (CIAT), 1994. Chapter 2. p.19-27.

VAN SOEST, P.J. Nutritional ecology of ruminant. New York: Cornell University Press, 1982. 373p.

VAN SOEST, P.J. Symposium on factors influencing the voluntary intake of herbage by ruminants: voluntary intake in relation to chemical composition and digestibility. Journal of Animal Science, v.24, n.3, p.834-843, 1965.

WILSON, J.R.; T'MANNETJE, L. Senescence, digestibility and carbohydrate content of buffel gran and green panic leaves in swards. Australian Journal Agricultural Research, v.29, p.503-519, 1978.

ZUIN, G.C.; VIDIGAL FILHO, P.S.; KVITSCHAL, M.V. et al. Divergência genética entre genótipos de mandioca-de-mesa coletados no município de Cianorte, região Noroeste do Estado do Paraná. Semina: Ciências Agrárias, v.30, n.1, p.21-30, 2009. 